\title{
PCR Clamping
}

\author{
Henrik Ørum \\ PNA Diagnostics A/S, Rønnegade 2, 6.floor, \\ 2100 Copenhagen $\varnothing$, Denmark
}

\section{Abstract}

An efficient, PCR based method for the selective amplification of DNA target sequences that differs by a single base pair is described. The method utilises the high affinity and specificity of PNA for their complementary nucleic acids and that PNA cannot function as primers for DNA polymerases.

\section{Introduction}

Methods that facilitate the rapid detection of single base pair mutations in DNA are of considerable importance in DNA diagnostics and the emerging field of pharmacogenetics. As the diagnostic industry seeks to avoid problems with amplicon contamination by combining amplification and detection in a closed system, it is furthermore desirable that such mutation detection methods are compatible with these new formats. A popular method is to use allele specific primers in the amplification reaction. As shown by Kwok et al. (1), however, most 3 ' mismatches between a primer and its template do not significantly impair the $\mathrm{PCR}$ reaction.

To improve this situation we have developed a method that enhances the specificity of the PCR reaction by targeting the initial step involved in non-specific amplification (2), i.e., the binding of the primer to a mis- matched target sequence. As shown in Figure 1, the method operates by competition for a common target site between a PNA (complementary to the wild-type target sequence) and one of the PCR primers (complementary to the mutant target sequence), or vice versa. When the template contains the wild-type sequence, PNA binding will dominate over primer binding due to the higher affinity of the matched PNA for the target site. As PNA cannot be extended by the Taq-polymerase the effect of this binding is that the amplification reaction is impaired. When the mutant sequence is present, PCR primer binding will dominate over PNA binding with the resulting generation of amplicons.

PCR clamping can also operate by interfering with primer elongation (2). In one set-up the PNA is located at a distance from the PCR primer. In this case, clamping is expected to operate by elongation arrest. In another setup the PNA is located adjacent to one of the PCR primers. Here, clamping is expected to operate by preventing initiation of primer elongation.

In order for the clamping reaction to function efficiently the fully complementary PNA must bind to its target sequence ahead of binding of the mismatched DNA primer, or vice versa. The most important variables that affects this ordered addition of oligos are the $T_{m}$ of the PNA and DNA for their respective target sites, the concentration of the PNA and DNA primer and the kinetics of PNA and DNA hybridization. In order to reduce the effects of PNA concentration and kinetics we expanded the normal 3 step PCR cycle with a PNA annealing step which is set at a temperature where only the fully complementary PNA can bind to its target site (Figure 2).
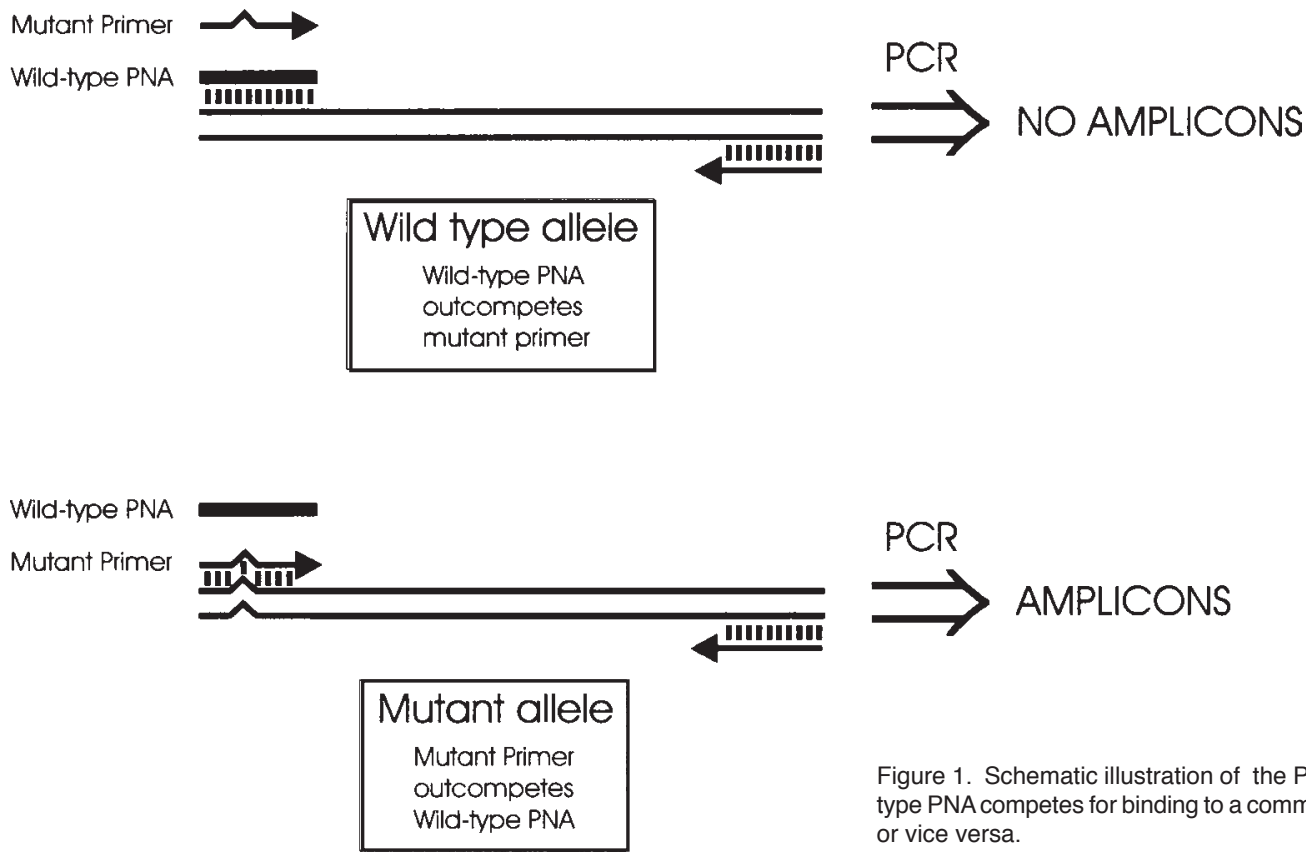

Figure 1. Schematic illustration of the PCR clamping method where wildtype PNA competes for binding to a common target with mutant PCR primer, or vice versa. 
Table 1. Effect of leaky clamping on the generation of amplicons during the PCR cycle. An asymmetrical development in the two amplicons strands are observed, since only one of the PCR primers are being targeted by the PNA clamp.

\begin{tabular}{ccccccc}
\hline \multirow{2}{*}{$\begin{array}{c}\text { No. of } \\
\text { PCR } \\
\text { cycles }\end{array}$} & $\begin{array}{c}\text { 1\% leakiness } \\
\text { Unclamped }\end{array}$ & Clamped & \multicolumn{2}{c}{$5 \%$ leakiness } & \multicolumn{2}{c}{$10 \%$ leakiness } \\
Unclamped & Clamped & Unclamped & Clamped \\
\hline 0 & 1 & 1 & 1 & 1 & 1 & 1 \\
5 & 1 & 6 & 2 & 7 & 3 & 8 \\
10 & 2 & 13 & 5 & 20 & 10 & 32 \\
15 & 2 & 22 & 13 & 56 & 41 & 128 \\
20 & 4 & 36 & 35 & 155 & 160 & 507 \\
25 & 6 & 59 & 95 & 425 & 633 & 2003 \\
30 & 10 & 96 & 261 & 1165 & 2502 & 7911 \\
\hline
\end{tabular}

An important aspect of the clamping method is that it does not require complete blocking of all the target sites in each cycle to work efficiently. In the set-up shown in Figure 1 , where one of the PCR primers is subject to clamping and one is not, the effect of incomplete blocking on the generation of either of the two amplicon strands can be calculated by the formulas:

$$
\begin{aligned}
& N_{C, x}=N_{C, X-1}+N_{U, X-1} \\
& N_{U, X}=(L-1) N_{C, X-1}+N_{C, x}
\end{aligned}
$$

Where $\mathrm{N}_{c, x}$ and $\mathrm{N}_{c, x-1}$ are the number of clamped strands (the amplicon strand to which the PNA hybridizes) at PCR cycle number $X$ and $X-1$, respectively. $\mathrm{N} u, x$ and $N u, X-1$ are the number of unclamped strands at cycle number $X$ and $X-1$, respectively, and $L$ is the fraction of strands that are not clamped in each PCR cycle. Table 1 shows how the number of unclamped and clamped strands develop in the course of a 30 cycle PCR with $1 \%, 5 \%$ or $10 \%$ leakiness in each cycle. As is evident, even $10 \%$ leakiness leads to only modest amplification factors (2502 fold; unclamped strand) and (7911 fold; clamped strand).

\section{Protocols}

Clamping operates by physical competition between a PNA and a DNA primer for a common target site. Optimisation of the clamping reaction is therefore largely a question of fine-tuning the thermostability of the PNA and DNA primer such that they will each out-compete the other in binding to their fully complementary target sites. When using the clamping set-up depicted in Figure 1, we use the following protocol to design the PNA and PCR primers.

Synthesize a PNA against the wild-type allele which spans the area in which the mutation is located. As a rule of thumb we design the PNA such that its $T_{m}$ is between $65^{\circ} \mathrm{C}$ and $75^{\circ} \mathrm{C}$ and such that the mutation to be detected is located in the middle of the PNA.

Previously, we obtained PNAs with the desired $T_{m}$ by synthesizing a panel of PNAs in the size range from 13 to 18 mers from which the appropriate oligo could subsequently be selected. With the recent publication of an empirical formula for predicting the $T_{m}$ of a PNA for its complementary target DNA (3) this time consuming approach can now be avoided.

Synthesize a series of DNA primers against the mutant target site which covers the size range from 5 to 10 nt. larger (at the 5' end) than the PNA. Design the DNA panel such that the mutation to be detected is located in the centre of the +7 oligo.

Establish the PCR reactions using the complementary and mismatched target DNA with the + 5 DNA primer and incorporating a PNA annealing step set at the $T_{m}$ of the fully complementary PNA $-5^{\circ} \mathrm{C}$. Test the ability of different concentrations of the PNA (typically from 1 to $10 \mu \mathrm{M}$ ) to block either of the two PCR reactions.

Use larger DNA primers and the lowest PNA concentration if both complementary and mis-matched target DNA is clamped. Lower the temperature of the PNA annealing step and use the highest concentration of PNA if no blocking is observed.

\section{Examples}

The PCR clamp method has been used successfully by several laboratories to detect small genetic alterations. Thiede et al. (4) used a slightly modified set-up to simultaneously analyse for six different point mutations in codon 12 and 13 of the K-ras gene (Figure 3). In their setup, a generic PCR primer (which amplifies both mutant and wild-type alleles) is located immediately downstream

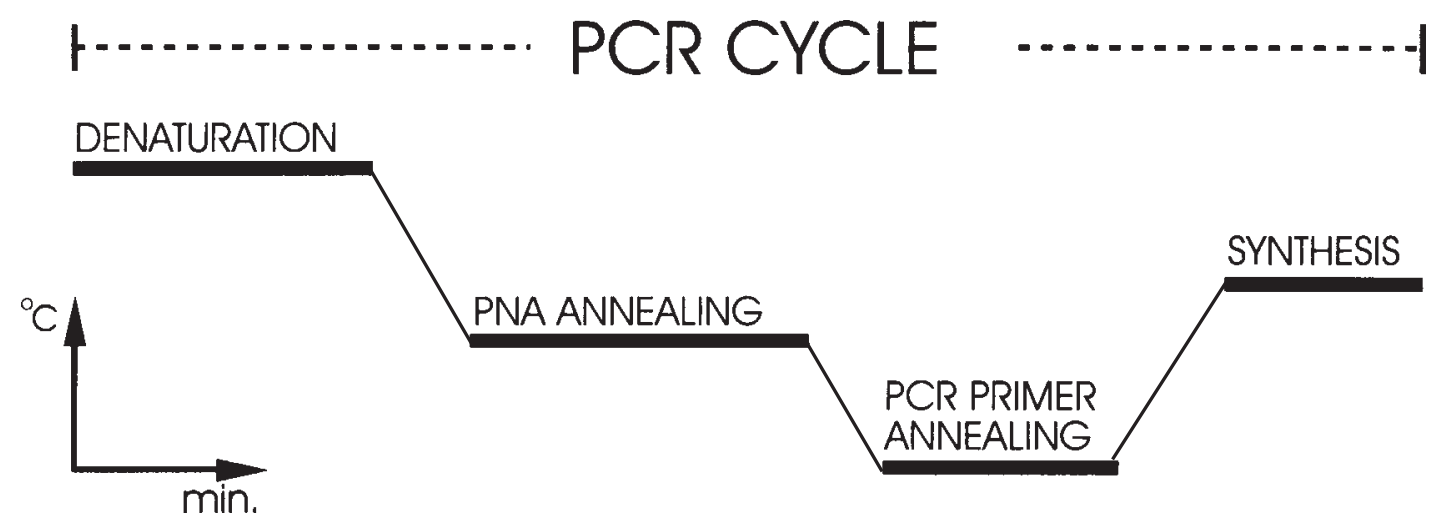

Figure 2. Schematic illustration of the four step PCR cycle profile used in PCR clamping. The PNA annealing step is set at a temperature that allows only the complementary PNA to bind. 


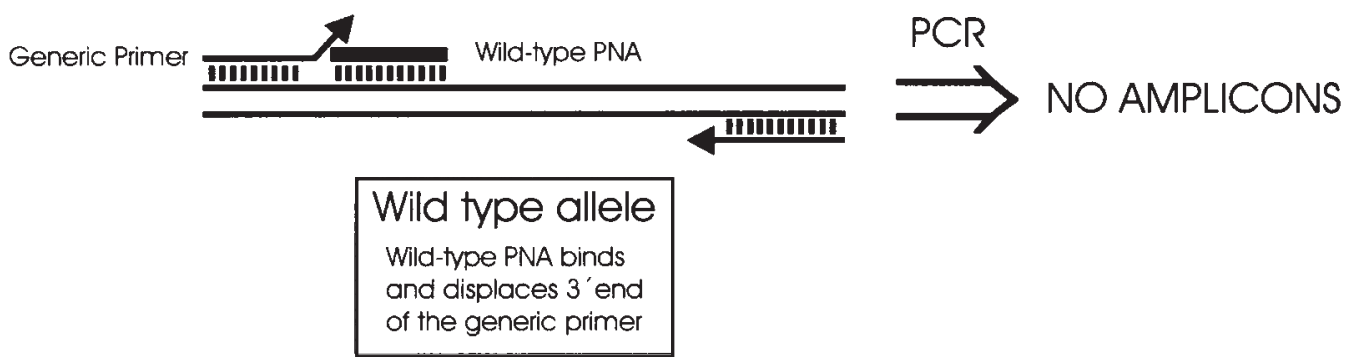

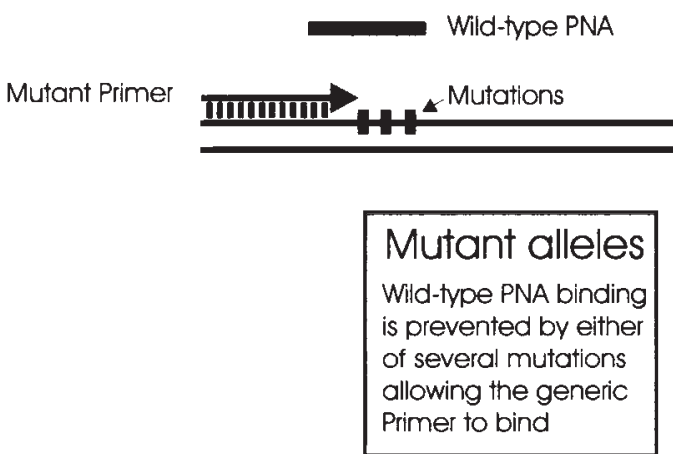

of the region containing the mutations. A PNA complementary to the wild-type sequence surrounds the mutations and partially overlaps the $3^{\prime}$ end of the primer binding site. When the wild-type gene is present, PNA binding excludes binding of the $3^{\prime}$ end of the PCR primer thereby preventing amplification. Mutations in codon 12 or 13 destabilises PNA binding thus allowing PCR primer binding and amplification. The method allowed the detection of all tested mutant alleles in the presence of a 200 fold excess of the wild-type allele.

Behn and Schuermann (5) used a similar set-up with overlapping PNA and PCR primer to detect carriers of the factor $V$ Leiden mutation that is the most common cause of thrombophilia. Results from a prospective study of 60 patients were in $100 \%$ concordance with those obtained by the commonly used PCR-RFLP detection method.

The PCR-clamping method has also been used in combination with other amplification/detection methods. Behn and Schuermann (6) used PNA clamping as a means to increase the sensitivity of detection of p53 mutant alleles by single-strand conformational polymorphism (PCRSSCP). The PNAs were located between the PCR primers and were complementary to the wild-type sequences corresponding to a known mutational "hot-spot" region in exon 7 of the p53 gene. In a survey of 20 samples from patients with lung cancer, the PNA-clamp-SSCP method allowed detection of point mutations in 4 samples which could not be detected by the standard PCR-SSCP approach.

Rhodes et al. (7) reported that PNA clamping could be used to increase the ability of allele specific oligos (ASO) to selectively amplify K-ras alleles with either a $G$ to $A$ transition or $G$ to $T$ transversion in codon 12. Mutant DNA was mixed with a large excess of wild-type DNA and subjected to 20 cycles of amplification using a set of generic
PCR primers and PNAs directed against the wild-type sequence surrounding codon 12 . The product of the initial PCR reaction was then diluted 10,000 fold and subjected to PCR amplification using the ASO's. The combined PNA/ ASO approach improved the ability to score mutant alleles in the presence of wild-type alleles by a factor of 5-10 compared to ASO-PCR alone.

Mrozikiewicz et al. $(8,9)$ used the PCR clamp method in combination with RFLP analysis to investigate 3 different mutations ( $\mathrm{m} 1, \mathrm{~m} 2$ and $\mathrm{m} 4)$ in the human cytochrome P$4501 \mathrm{~A} 1$ gene in a group of 324 individuals of Slavic origin. A particular objective of the study was to determine the allelic linkage of the mutations. This was successfully achieved by performing multiple PCRs on each patient sample using mutant specific PNAs either alone or in combination. The rationale behind this approach is as follows. If for instance the $\mathrm{m} 1$ and $\mathrm{m} 2$ mutations are placed on different alleles, then amplicons will be generated when either the $\mathrm{m} 1$ or m2-PNA are used alone but not when they are used in combination. Conversely, if $\mathrm{m} 1$ and $\mathrm{m} 2$ are placed on the same allele, then amplicons will be generated independent of whether the $\mathrm{m} 1$ and m2-PNA are used alone or in combination.

Several methods have been developed that uses sequence specific fluorescent probes (10-11) or double strand DNA-selective fluorescent dyes (12) to monitor the progress of an amplification reaction in real-time. The speed and convenience of these methods and the ability to control laboratory contamination by amplified products, constitutes an important technical advance in the quest for making large scale DNA diagnostics commercially feasible.

Recently, Kyger et al. (13) used the PCR clamp method in the context of real-time fluorescence detection of amplicons by the dsDNA selective dye Sybr Green I. Using the set-up shown in Figure 1, the authors successfully 
detected a single base pair mutation in the HFE gene (14) which has been associated with Heriditary hemochromatosis (a common autosomal recessive disease that results in excessive iron deposition in major organs of the body).

Most of the reports on the PCR clamp method have monitored the amplicons at the end of the amplification reaction. As such, a small non-specific inhibition of amplification by the PNAs would probably have gone undetected. Using real-time detection, however, even small effects can be detected by monitoring increases in the threshold cycle $\left(\mathrm{C}_{\mathrm{T}}\right.$; the cycle at which the emission intensity of the sample rises above the baseline). Using a heterozygous target DNA and PNA in 18-fold excess over PCR primer Kyger et al. (13) observed an increase in $\mathrm{C}_{T}$ from 26 to 27 cycles with combinations of WT-primer/MUTPNA and MUT-primer/WT-PNA. Since one of the alleles in the heterozygous sample was subject to clamping, these data indicates that non-specific inhibition by the PNA is minimal.

\section{Perspectives}

Of the various PNA based technologies developed so far the PCR clamp method is the one that has found most widespread use. We believe that this is a tribute to both good performance, ease of optimisation and flexibility.

As demonstrated by several authors the method is compatible with other PCR methods. For instance, PNA clamping could be used to improve the selective amplification of closely similar sequences by allele specific oligos (7) or as a prelude to subsequent detection of allelic variants by SSCP (6). Likewise, it was possible to combine the clamping method with real-time fluorescence detection of amplicons by a double strand DNA-selective dye in a closed system (13). Given the trend towards such formats in the diagnostic industry this demonstration is of significant importance.

All current reports on PNA clamping are in the context of the PCR reaction. We expect, however, that the approach will be applicable to other amplification technologies such as for instance LCR (15) and NASBA (16).

\section{Note}

This article is a journal version of book chapter (17) reprinted by the publisher with the author's permission.

\section{References}

1. Kwok, S., Kellogg, D.E., McKinney, N., Spasic, D., Goda, L., Levenson, C. and Sninsky, J.J. 1990. Effects of primer-template mismatches on the polymerase chain reaction: Human immunodeficiency virus type 1 model studies. Nucl. Acid Res. 18: 999-1005.

2. Ørum, H., Nielsen, P.E., Egholm, M., Berg, R.H., Buchardt, O. and Stanley, C. 1993. Single base pair mutation analysis by PNA directed PCR clamping. Nucl. Acid Res. 21: 5332-5336.

3. Giesen. U., Kleider, W., Berding, C., Geiger, A., Ørum, H. and Nielsen. P. E. 1998. A formula for thermal stability $\left(\mathrm{T}_{\mathrm{m}}\right)$ prediction of PNA/DNA duplexes. Nucl. Acid Res. 26: 5004-5006.

4. Thiede, C., Bayerdörffer, E., Blasczyk, R., Wittig, B. and Neubauer, A. 1996. Simple and sensitive detection of mutations in the ras proto-oncogenes using PNAmediated PCR clamping. Nucl. Acid Res. 24: 983-984.

5. Behn, M. and Schuermann, M. 1998. Simple and reliable factor $\mathrm{V}$ genotyping by PNA-mediated PCR clamping. Thromb Haemost, 79: 773-777.

6. Behn, M. and Schuermann, M. 1998. Sensitive detection of $p 53$ gene mutations by a "mutant enriched" PCR-SSCP technique. Nucl. Acid Res. 26: 1356-1358.

7. Rhodes, C. H., Honsinger, C., Porter, D. M. and Sorenson, G. D. 1997. Analysis of the allele-specific PCR method for the detection of neoplastic disease. Diag. Mol. Pathol. 6: 49-57.

8. Mrozikiewicz, P. M., Cascorbi, I., Brockmöller, J. and Roots, I. 1997. CYP1A1 mutations 4887A, 4889G, $5639 \mathrm{C}$ and $6235 \mathrm{C}$ in the polish population and their allelic linkage determined by peptide nucleic acidmediated PCR clamping. Pharmacogenetics. 7: 303307.

9. Mrozikiewicz, P. M., Landt, O., Cascorbi, I. and Roots, I. 1997. Peptide nucleic acid-mediated polymerase chain reaction clamping allows allelic allocation of CYP1A1 mutations. Anal. Biochem. 250: 256-257.

10. Holland, P., Abramson, R. D., Watson, R. and Gerlfand, D. H. 1991. Detection of specific polymerase chain reaction product by utilising the $5^{\prime}-3^{\prime}$ exonuclease activity of Thermus aquaticus DNA polymerase. Proc. Natl. Acad. Sci. USA. 88: 7276-7280.

11. Tyagi. S. and Kramer, F. R. 1996. Molecular beacons: Probes that fluoresce upon hybridization. Nature Biotech. 14: 303-308.

12. Wittwer, C. T., Herrmenn, M. G., Moss, A. A. and Rasmussen, R. P. 1997. Continous fluorescence monitoring of rapid cycle DNA amplification. Biotechniques. 22: 130-138.

13. Kyger, E. M., Krevolin, M. D. and Powell, M. J. 1998. Detection of the hereditary hemochromatosis gene mutation by real-time fluorescence polymerase chain reaction and peptide nucleic acid clamping. Anal. Biochem. 260: 142-148.

14. Feder, J.N., Gnirke, A., Thomas, W., Tsuchihashi, Z., Ruddy, D.A., Basava, A., Dormishian, F., Domingo, R. Jr., Ellis, M.C., Fullan, A., Hinton, L.M., Jones, N.L., Kimmel, B.E., Kronmal, G.S., Lauer, P., Lee, V.K., Loeb, D.B., Mapa, F.A., McClelland, E., Meyer, N.C., Mintier, G.A., Moeller, N., Moore, T., Morikang, E., Prass, C. E., Quintana, L., Starnes, S. M., Schatzman, R. C., Brunke, K. J. Drayna, D. T., Risch, N. J., Bacon, B. R. and Wolff, R.K. 1996. A novel MHC class I-like gene is mutated in patients with hereditary haemochromatosis. Nature Genet. 13: 399-408

15. Barany, F. 1991. Genetic disease detection and DNA amplification using cloned thermostable ligase. Proc. Natl. Acad Sci. USA. 88: 189-193

16. Kievits, T., van Gemen, B., van Strijp, D., Schukkink, R., Dircks, M., Adriaanse, H., Malek, L., Sooknanan, R. and Lens, P. 1991. NASBA ${ }^{\text {TM }}$ isothermal enzymatic in vitro nucleic acid amplification optimised for the diagnosis of HIV-1 infection. J. Virol. Methods. 35:273286.

17. Ørum, H. 1999. PCR Clamping. In: Peptide Nucleic Acids: Protocols and Applications. P.E. Nielsen and M. Egholm, eds. Horizon Scientific Press, Wymondham, UK. p. 175-184. 


\section{Further Reading}

Caister Academic Press is a leading academic publisher of advanced texts in microbiology, molecular biology and medical research. Full details of all our publications at caister.com

- MALDI-TOF Mass Spectrometry in Microbiology Edited by: M Kostrzewa, S Schubert (2016) www.caister.com/malditof

- Aspergillus and Penicillium in the Post-genomic Era Edited by: RP Vries, IB Gelber, MR Andersen (2016) www.caister.com/aspergillus2

- The Bacteriocins: Current Knowledge and Future Prospects Edited by: RL Dorit, SM Roy, MA Riley (2016)

www.caister.com/bacteriocins

- Omics in Plant Disease Resistance Edited by: V Bhadauria (2016) www.caister.com/opd

- Acidophiles: Life in Extremely Acidic Environments Edited by: R Quatrini, DB Johnson (2016) www.caister.com/acidophiles

- Climate Change and Microbial Ecology: Current Research and Future Trend

Edited by: J Marxsen (2016)

www.caister.com/climate

- Biofilms in Bioremediation: Current Research and Emerging Technologies

Edited by: G Lear (2016)

www.caister.com/biorem

- Microalgae: Current Research and Applications Edited by: MN Tsaloglou (2016) www.caister.com/microalgae

- Gas Plasma Sterilization in Microbiology: Theory, Applications, Pitfalls and New Perspectives Edited by: H Shintani, A Sakudo (2016) www.caister.com/gasplasma

- Virus Evolution: Current Research and Future Directions Edited by: SC Weaver, M Denison, M Roossinck, et al. (2016) www.caister.com/virusevol

- Arboviruses: Molecular Biology, Evolution and Control Edited by: N Vasilakis, DJ Gubler (2016) www.caister.com/arbo

- Shigella: Molecular and Cellular Biology Edited by: WD Picking, WL Picking (2016) www.caister.com/shigella

-Aquatic Biofilms: Ecology, Water Quality and Wastewater Treatment

Edited by: AM Romaní, H Guasch, MD Balaguer (2016)

www.caister.com/aquaticbiofilms

- Alphaviruses: Current Biology

Edited by: S Mahalingam, L Herrero, B Herring (2016)

www.caister.com/alpha

- Thermophilic Microorganisms

Edited by: F Li (2015)

www.caister.com/thermophile
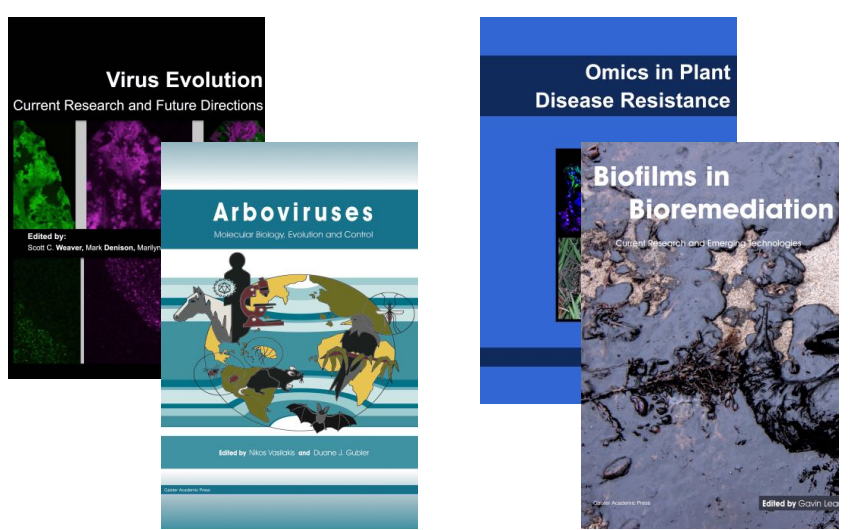
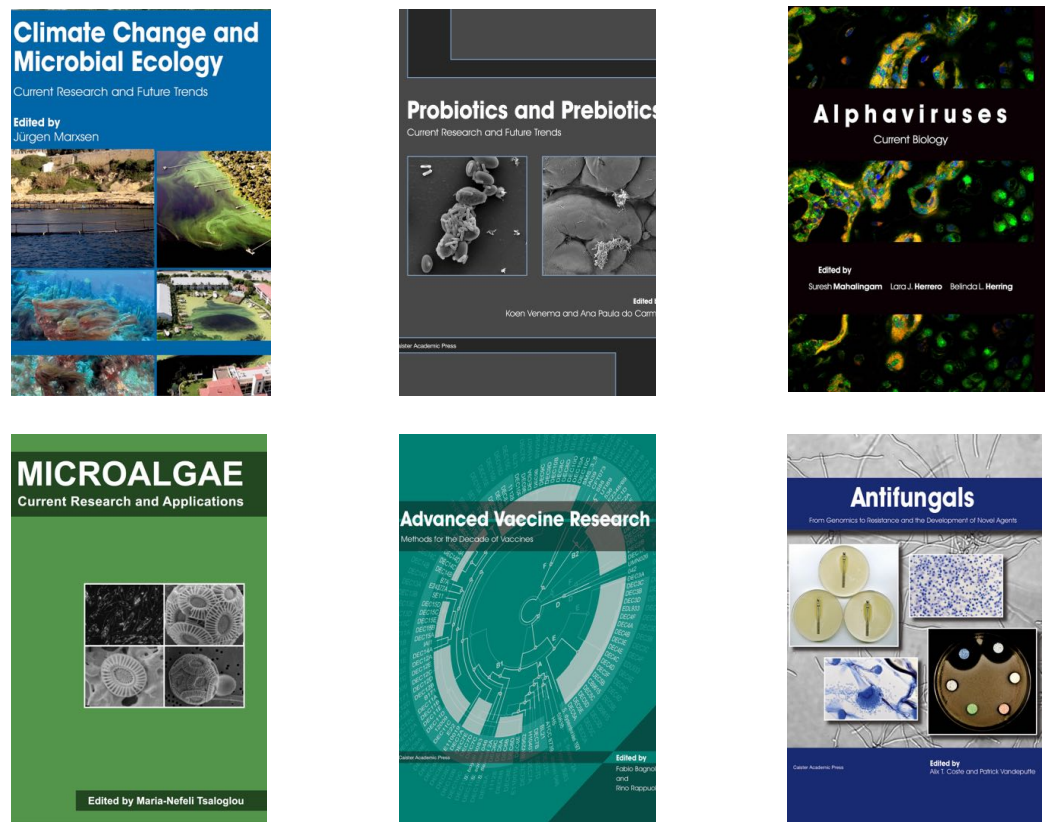

- Flow Cytometry in Microbiology: Technology and Applications Edited by: MG Wilkinson (2015) www.caister.com/flow

- Probiotics and Prebiotics: Current Research and Future Trends Edited by: K Venema, AP Carmo (2015) www.caister.com/probiotics

- Epigenetics: Current Research and Emerging Trends Edited by: BP Chadwick (2015) www.caister.com/epigenetics2015

- Corynebacterium glutamicum: From Systems Biology to Biotechnological Applications

Edited by: A Burkovski (2015)

www.caister.com/cory2

- Advanced Vaccine Research Methods for the Decade of Vaccines

Edited by: F Bagnoli, R Rappuoli (2015)

www.caister.com/vaccines

- Antifungals: From Genomics to Resistance and the Development of Novel Agents

Edited by: AT Coste, P Vandeputte (2015)

www.caister.com/antifungals

- Bacteria-Plant Interactions: Advanced Research and Future Trends Edited by: J Murillo, BA Vinatzer, RW Jackson, et al. (2015) www.caister.com/bacteria-plant

\section{- Aeromonas}

Edited by: J Graf (2015)

www.caister.com/aeromonas

- Antibiotics: Current Innovations and Future Trends

Edited by: S Sánchez, AL Demain (2015)

www.caister.com/antibiotics

- Leishmania: Current Biology and Contro Edited by: S Adak, R Datta (2015) www.caister.com/leish2

- Acanthamoeba: Biology and Pathogenesis (2nd edition) Author: NA Khan (2015)

www.caister.com/acanthamoeba2

- Microarrays: Current Technology, Innovations and Applications Edited by: Z He (2014)

www.caister.com/microarrays2

- Metagenomics of the Microbial Nitrogen Cycle: Theory, Methods and Applications

Edited by: D Marco (2014)

www.caister.com/n2 